\title{
A ADMINISTRAÇÃO PÚBLICA EM FACE DA RESPONSABILIDADE AMBIENTAL
}

TOSHIO MUKAI*

\begin{abstract}
I - Introdução - II - A Administração em face da responsabilidade administrativa do poluidor (ou eventual) $-a$ ) - o controle prévio através do licenciamento ambiental - b) - o estudo de impacto ambiental, novas regras - c) - as sanções administrativas - III - A administração Pública e a responsabilidade civil (objetiva) do poluidor IV - A responsabilidade ou criminalização dos atos danosos ao meio ambiente - As recentes sanções penais - V - Comunicabilidade $e$ incomunicabilidade das instâncias penais, administrativas e civil.
\end{abstract}

\section{I - Introdução}

A Administração Pública detém papel relevante em face das responsabilidades decorrentes do dano ambiental.

De um lado, observe-se que a Constituição impõe ao Poder Público (assim como à coletividade) o dever de defender o meio ambiente e preservá-lo para as presentes e futuras gerações.

Aqui aparecem, então, as leis administrativas, que dizem respeito ao exercício do poder de polícia administrativa em matéria ambiental, que na espécie, guardam três fundamentais ações da Administração Pública: o licenciamento ambiental (controle prévio), a elaboração e aprovação (ou não) do estudo de impacto ambiental e a aplicação de sanções.

* Mestre e Doutor em Direito (USP). Membro da Comissão de Meio Ambiente do Conselho Federal da OAB; Secretário da Sociedade Brasileira do Direito do Meio Ambiente; Professor no Curso de Direito Ambiental - Pós-Graduação, "Latu-Sensu", na Universidade de São Paulo; Professor convidado no Curso de Pós-Graduação em Direito Ambiental da UnB/OAB-DF, membro-fundador da Associação Brasileira dos Advogados Ambientalistas - ABAA. 
Entretanto, sabemos que a responsabilidade do causador do dano ao meio ambiente, além de ser de ordem administrativa, também é de natureza civil (responsabilidade objetiva) e penal (Lei $\mathrm{n}^{2}$ 9.605/98).

Já se vê que a Administração Pública, enquanto Poder Executivo, tem a ver com a responsabilidade administrativa apenas, porquanto as duas outras são da alçada, quanto às suas aplicações e concretizações, do Poder Judiciário.

Assim, parece-nos que o tema que enfrentamos diz respeito às ações decorrentes do poder de polícia administrativa. Entretanto, como há complementariedade entre as defesas penal e civil com a administrativa, ainda que sucintamente, haveremos de nos debruçar sobre aquelas duas modalidades de responsabilidade, para, ao final, verificarmos se há ou não influência de uma esfera sobre a outra.

\section{II - A Administração em face da responsabilidade administrativa do poluidor (ou eventual)}

Para empenhar a responsabilidade administrativa do eventual poluidor, a Administração Pública utiliza-se, como já dito, do seu poder de polícia.

Como o Brasil é uma Federação, compreendendo a União, os Estados, o Distrito Federal e os Municípios, todos autônomos (art. 18 da C.F), há que adentrar, ainda que perfunctoriamente, o tema das competências das unidades federadas, no exercício da função administrativa, que, lembre-se, só pode ser exercida em função e nos limites de leis formais autorizativas (princípio da legalidade).

Em tema de exercício do poder de polícia ambiental, matéria administrativa, por excelência, há que se pontuar três tipos de competências, das diversas esferas administrativas: a privativa, a concorrente e a comum.

Todas, quanto ao alcance e objetivos básicos de suas concretizações, são diferentes entre si.

Assim, enquanto as normas de competência privativa, previstas nos arts. 21 e 22 (para a União), 25 (para os Estados) e 30 (para os Municípios) são de aplicação de acordo com o interesse predominante de cada qual (União, normas nacionais e regionais supra-Estados; Estados, normas regionais, supra-municipais e Municípios, locais) as normas de competência concorrente são de aplicação, tanto pela União, como pelos Estados e Municípios (art. 24), valendo para todo o território nacional; porém, limitam-se às normas gerais. Finalmente as normas de competência comum (se existentes) devem observar um vetor constitucional que nos é dado pelo parágrafo único do art. 23, ou seja, como essa disposição prevê uma Lei Complementar que deverá fixar normas de cooperação entre as unidades federadas em matéria ambiental, dentre outras, conclui-se que, o exercício da competência comum, por qualquer delas, deve observar o objetivo da cooperação e não a disputa de poder para aquele exercício. Não há, aqui, lugar para o exercício isolado e não cooperativo do poder de polícia ambiental, por qualquer esfera de governo. Esta competência somente será legítima, se exercitada em forma de cooperação.

Visto isso, passemos às três fases da responsabilidade administrativa do poluidor, a do controle prévio (licenciamento ambiental) a da antecedência ou não de estudo de impacto ambiental, à da aplicação das sanções administrativas: 


\section{a) - o controle prévio através do licenciamento ambiental}

O controle administrativo preventivo das atividades, obras e empreendimentos que possam causar danos ao meio ambiente deve ser efetuado por meio de autorizações, no geral (e não através de licenças, o que ocorre apenas e tão-somente no campo do direito de construir); em casos especiais, de utilizações de bens de domínio público (ex.: recursos hídricos), os instrumentos jurídicos apropriados devem ser a concessão administrativa ou a permissão de uso.

O art. 225, caput, da Constituição declarou que o meio ambiente, no Brasil, é bem de uso comum do povo; portanto, ninguém, individualmente, tem o direito subjetivo a ele (e seus componentes), o que, em conseqüência, faz com que a permissividade do exercício de qualquer atividade, de construções de obras e empreendimentos, seja feita pelo Poder Público, de modo discricionário, pela via própria, que, no caso, é a da autorização, e não pela via da licença administrativa, que por remover obstáculos ao livre exercício de um direito subjetivo (p.ex.: direito de construir, que é um direito e garantia constitucional), é um ato administrativo vinculado (à legislação e regulamentos administrativos).

Portanto, como bem salienta Paulo Afonso Leme Machado, o emprego na legislação e na doutrina do termo licenciamento ambiental não traduz necessariamente a utilização da expressão "licença", em seu rigor técnico (cf. Direito Ambiental Brasileiro, R.T., $3^{\mathrm{a}}$ ed., 1991, p. 164). E, como invoca ainda o mesmo autor, atente-se que, na matéria, R. Villata afirma que "o escopo de prevenção sempre foi entendido como típico da categoria da autorização" e M.S. Giannini salienta que "em todo o caso ocorre especial autorização se o estabelecimento produz poluição atmosférica ou hídrica" (ob. Cit., p. 164).

Portanto, quando a Lei $\mathrm{n}^{\circ} 6.938 / 81$ prevê que o licenciamento ambiental e a revisão do licenciamento de atividade efetiva ou potencialmente poluidoras são instrumentos da Política Nacional do Meio Ambiente, após a Constituição de 1988, por força do seu art. 225, caput, não resta dúvida nenhuma de que tais expressões devem ser entendidas como sinônimas de autorizações, atos administrativos precário e discricionários.

O mesmo se diga em relação a toda e qualquer legislação de âmbito estadual ou municipal, onde seja empregada a expressão licença (ou licenciamento).

Relativamente aos recursos hídricos, posto que, como já visto, em grande parte, se trata de bens públicos de uso comum ou até dominicais, ou da União, ou dos Estados-membros, sua utilização deverá ser outorgada mediante concessões (contratos administrativos) ou permissões (atos unilaterais, precários e discricionários).

\section{b) - o estudo de impacto ambiental, novas regras}

A Lei $\mathrm{n}^{2} 6.938$, de 31.08.81 (que dispõe sobre a Política Nacional do Meio Ambiente) criou o CONAMA como órgão máximo Consultivo e Deliberativo do Sistema Nacional do Meio Ambiente. 
E a ele, dentre outras atribuições (art. $8^{\mathfrak{}}$ ), outorgou a atribuição de "estabelecer, mediante proposta do IBAMA, normas e critérios para o licenciamento de atividades efetivas e potencialmente poluidoras, a ser concedido pelos Estados e supervisionando pelo IBAMA".

Tendo em vista que o art. $9^{2}$ da mencionada Lei contemplou, como um dos instrumentos da Política Nacional do Meio Ambiente, a avaliação de impactos ambientais, o CONAMA, em 23 de janeiro de 1986, baixou a Resolução $\mathrm{n}^{\circ} 001$, estabelecendo critérios, competências, hipóteses, definições, diretrizes gerais para a exigência dos estudos de impacto ambiental e para o licenciamento de atividade em face da proteção ambiental.

Assim, logo no art. $2^{\circ}$ da referida Resolução, ficou expresso: o estudo de impacto ambiental e respectivo relatório de impacto ambiental - RIMA, a serem submetidos à aprovação do órgão estadual competente e da SEMA, em caráter supletivo, o licenciamento de atividades modificadoras do meio ambiente, tais como:" (listam-se diversas atividades, de I a XVIII).

Pois bem, como se viu, essa legislação é anterior à Constituição de 1988, e, portanto, essa competência privativa do Estado-membro e de SEMA, embora altamente discutível quanto à sua constitucionalidade, já que afasta o Município, em todas as suas hipóteses, foi fixada, tendo em vista que a Emenda Constitucional $\mathbf{n}^{\circledR}$ 1/69 não era expressa quanto à determinação das competências para aquele mister.

Ocorre que a Constituição de 1988 veio declarar, expressamente, que as competências, em matéria ambiental, são de natureza comum. (art. 23), privativas e concorrentes como vimos.

E, quanto aos estudos de impacto ambiental, somente as atividades ou obras potencialmente causadoras de significativa degradação do meio ambiente exigem estudo prévio de impacto ambiental (inciso IV, do $\S 1^{\circledR}$ do art. $225 \mathrm{da} C F$ ).

Dessa forma, a referida Resolução CONAMA $n^{0} 001$, de 31.08 .81 , restou desconforme com a Constituição federal de 88 , não tendo sido por ela recepcionada em dois aspectos: no ponto em que fixava a competência exclusiva do Estado-membro para as licenças ambientais e, portanto, para a exigência do estudo prévio de impacto ambiental, e no ponto em que exigia o referido estudo para toda e qualquer atividade simplesmente modificadora do meio ambiente.

Por essa razão, na realidade, a mencionada Resolução, nesse aspecto, estava derrogada pela Constituição de 1988. Não obstante, a maioria dos órgãos estaduais ambientais, senão todos, davam-lhe aplicação, posto que nenhuma outra a modificara.

Ocorre que, no final de 1997, o CONAMA baixou a nova Resolução de $n^{\circledR} 237$ de 19.12.97 (DOU-22.12.97), onde, finalmente, essas defasagens da legislação pertinente foram supridas.

Dentre as várias disposições novas que dela constam, pretendemos, aqui, apenas sublinhar aquelas que corrigiram as distorções da Resolução CONAMA $n^{\mathfrak{Q}}$ 001, em face da Constituição de 1988.

2. A primeira correção é quanto às competências para o licenciamento que, adaptadas agora à competência comum do art. $23 \mathrm{da} \mathrm{CF}$, passam a ser: 
a) do IBAMA no caso de empreendimentos e atividades com significativo impacto ambiental de âmbito nacional ou regional: a saber (são apontadas 5 hipóteses);

b) do órgão ambiental estadual ou do Distrito Federal apenas e tão-somente nos casos de empreendimentos e atividades:

I - localizados ou desenvolvidos em mais de um Município ou em unidades de conservação de domínio estadual ou do DF;

II - localizados ou desenvolvidos nas florestas e demais formas de vegetação natural de preservação permanente relacionados no art. $2^{\circ}$ da Lei $n^{2} 4.771 / 65$, e em todas as que assim forem consideradas por normas federais, estaduais ou municipais;

III - cujos impactos ambientais diretos ultrapassam os limites de um ou mais municípios;

c) do órgão ambiental municipal (ouvidos os órgãos competentes da União, dos Estados e do DF, quando couber) o licenciamento ambiental de empreendimentos e atividades de impacto ambiental local e daqueles que lhes forem delegados pelo Estado por instrumento legal ou convênio (art. $6^{\circ}$ ).

$\mathrm{O}$ art. $7^{\circ}$ dispõe que os empreendimentos e atividades serão licenciados em um único nível de competência, conforme estabelecido nos artigos anteriores.

$\mathrm{O}$ art. 20 da Resolução $n^{2} 237$ dispõe, finalmente, quanto à competência, que "os entes federados, para exercerem suas competências licenciatórias deverão ter implementados os Conselhos de Meio Ambiente, com caráter deliberativo e participação social e, ainda, possuam em seus quadros, ou à sua disposição, profissionais legalmente habilitados".

3. A segunda correção é quanto aos empreendimentos e atividades considerados efetiva e potencialmente causadores de significativa degradação do meio ambiente, que dependerão de prévio estudo de impacto ambiental e respectivo relatório sobre o meio ambiente (EIA/RIMA), ao qual dar-se-à publicidade, garantida a realização da audiências públicas, quando couber, de acordo com a regulamentação.

E o parágrafo único: "O órgão ambiental competente, verificando que a atividade ou empreendimento não é potencialmente causador de significativa degradação do meio ambiente, definirá os estudos ambientais pertinentes ao respectivo processo de licenciamento."

Verifica-se, assim, que a nova Resolução disciplinou de modo diferente a questão da exigência do estudo de impacto ambiental, pois, agora, não há mais, para qualquer empreendimento ou atividade, a referida exigência, adaptando-se à Constituição federal, que só o exige para casos de significativa degradação do meio ambiente.

E, nesse sentido, aquela relação prevista de obras e atividades sujeitas ao referido estudo, pelo art. $2^{\circ}$ da Resolução $\mathrm{n}^{\circ} 001 / 86$, não mais prevalece, pelo menos na sua generalidade.

Ademais, o $\S 1^{\varrho}$ do art. $2^{2}$ da nova Resolução fixou, no Anexo $n^{2} 1$, o rol de empreendimentos e atividades que estão sujeitos ao licenciamento ambiental e, portanto, à eventual exigência do estudo prévio de impacto ambiental. 
Observe-se que a questão de se saber quando determinada atividade pode ou não causar significativa degradação do meio ambiente é da competência discricionária e exclusiva do órgão ambiental competente.

Portanto, a exigência ou não do estudo mencionado, uma vez feita por esse órgão, não pode ser objeto de nenhuma reforma judicial sob pena de invasão da competência exclusiva dada pela legislação à administração ambiental, violando-se, assim, o princípio da independência e harmonia dos Poderes (art. $2^{\circ}$ da Constituição da República).

Um terceiro e último aspecto, relevante, da Resolução, é que ela incide imediatamente sobre os casos em tramitação nos órgãos competentes.

Com efeito, o art. 21 da Resolução dispõe que ela entra em vigor na data de sua publicação, aplicando seus efeitos aos processos de licenciamento em tramitação nos órgãos ambientais competentes, revogadas as disposições em contrário, em especial os arts. $3^{\circ}$ e $7^{\circ}$ da Resolução CONAMA no 001 , de 23 de janeiro de 1986.

\section{c) - as sanções administrativas}

1. Finalmente foi publicado o Regulamento da Lei n. .9 .605 , de 12.02.1998, que dispõe sobre as sanções administrativas e penais em matéria ambiental.

Sabe-se que o Governo Federal produziu uma primeira versão para o Regulamento, que pretendia ser aplicável a todas as esferas administrativas, o que foi abandonado logo depois.

Tendo surgido agora a versão final do Regulamento, convém verificar, se o Decreto n. .9379 de 21.09.1999 (DOU - 22.09.1999), manteve-se dentro dos cânones constitucionais, não atropelando as competências estaduais e/ou municipais quanto à aplicação das sanções administrativas ambientais.

2. Quando surgiu a Lei n. $.9 .605 / 98$, a propósito das sanções administrativas escrevemos: "Portanto, a Lei n. $.9 .605 / 98$, a par de ter estatuído um leque de sanções penais, com base na competência privativa da União (art. 22 da CF), estabeleceu uma série de disposições de natureza administrativa sancionatória, ambiental, que funcionam como normas gerais para a União, Estados, Distrito Federal e Municípios.

Assim, considerando esse aspecto relevante, é que teceremos comentários sobre as demais normas da Lei, relativas às sanções administrativas.

$O \S 1^{\circ}$, do art. 70 indica as autoridades competentes para a lavratura dos autos de infração ambiental e instauração do processo administrativo correspondente. São os funcionários dos órgãos ambientais integrantes do SISNAMA, designados para as atividades de fiscalização, bem como os agentes dos Capitanias do Portos.

Esses e somente esses são os funcionários competentes para aplicar as sanções administrativas de natureza ambiental, no País, posto que o $\S 1^{\circ}$ é norma geral de direito ambiental.

O $\S 4^{\circ}$ impõe o contraditório e a ampla defesa na apuração das infrações ambientais.

$\mathrm{O}$ art. 71 dispõe sobre o processo de apuração da infração ambiental, impondolhe prazos máximos. 
O inc. III, que prevê recurso da decisão condenatória à instância superior do SISNAMA, é inconstitucional, pois não pode haver hierarquia entre um órgão (ou funcionário) municipal e outro estadual. O recurso, se houver, deverá ser decidido no âmbito da entidade política que impôs a decisão condenatória. (cf. nosso, "Direito Ambiental Sistematizado", $3^{\text {a }}$ ed. - Ed. Forense Universitária, 1998, p. 92/93).

E mais adiante: " $O$ art. 72 elenca os tipos de sanções administrativas ambientais. São, ao todo, 11 (onze) tipos de sanções, valendo sublinhar as do inciso XI, aquelas restritivas de direitos.

Duas observações da maior importância, sob o ponto de vista jurídico: a) esses tipos sancionatórios são normas gerais, e como tal, não admitem que Estados e Municípios criem outros diferentes, em matéria ambiental; b) - a aplicação concreta dessas sanções tão-só com base direta na Lei $\mathrm{n}^{\circ} 9.605 / 98$, só pode ser levada a efeito pela União, pois se trata de lei federal; c) - em relação a Estados, Distrito Federal e Municípios, tais sanções - tipo, são normas gerais, e, como tal, não têm aptidão para poderem ser aplicadas por tais entidades políticas tão-só com base direta na Lei $n^{9}$ 9.605/98; há que se concretizar, antes, nas suas legislações próprias, tais sanções, inclusive quanto ao seu "quantum" (no caso da multa, por exemplo), para somente depois, poderem tais entidades federativas aplicar tais sanções aos infratores da regra de proteção ambiental" (ob. cit. p. 93).

3. Pois bem. O Regulamento baixado pelo Decreto $n^{2} 3.179 / 99$ repete que as sanções administrativas são aquelas 11 (onze), acrescentando a 12a: reparação dos danos causados. Esta sanção já vem prevista na Lei $n^{2}$ 6.938/81 (Lei da Política Nacional do Meio Ambiente) que elege a responsabilidade pelo dano ambiental como sendo objetiva, o que é repetido pelo $\S 10$ do art. $2^{\circ}$ do Decreto. As sanções restritivas de direitos, previstas na Lei $n^{\circ} 9.605 / 98$ ( $\S 8^{\circ}$ do art. 72) são repetidas pelo $\S 9^{\circ}$ do art. $2^{\circ}$ do Decreto.

O art. $8^{\varrho}$ do Decreto repete disposição da Lei n $9.605 / 98$ (art. 76): "O pagamento da multa por infração ambiental imposta pelos Estados, Municípios, Distrito Federal ou Territórios substitui a aplicação de penalidade pecuniária pelo órgão federal, em decorrência do mesmo fato, respeitados os limites estabelecidos neste Decreto", mas, com o acréscimo da parte final, sendo esse acréscimo, portanto, ilegal.

Com efeito, o art. 76 da Lei $\mathrm{n}^{2}$ 9.605/98 reza: "O pagamento de multa imposta pelos Estados, Municípios, Distrito Federal, ou Territórios substitui a multa federal na mesma hipótese de incidência".

Ou seja, a Lei respeita as autonomias legislativas e administrativas dos Estado, Municípios, D.F. e Territórios (para mais ou para menos das multas previstas no decreto).

O decreto pretende que, se a multa municipal (fixada em lei) for menor do que a prevista nele, a União poderá cobrar o faltante, o que a Lei não prevê. Segundo esta, deverá haver a substituição pura e simples.

Mas a importância dessa disposição (constante do Decreto) é que ela respeita as autonomias municipais e estaduais na fixação dos "quantuns" das multas.

4. Quanto às infrações administrativas, a Lei $n^{\circ} 9.605 / 98$ contém uma norma geral a respeito: "Art. 70 - Considera-se infração administrativa ambiental toda 
ação ou omissão que viole as regras jurídicas de uso, gozo, promoção, proteção e recuperação do meio ambiente".

O detalhamento dessa infrações, a Lei deixou para o Regulamento, valendo este somente para o nível federal, inclusive, relativamente aos "quantuns" das multas correspondentes.

Assim, o Decreto $n^{\circledR} 3.179 / 99$, no Cap. II, dispõe sobre as sanções aplicáveis às infrações cometidas contra o meio ambiente, indicando detalhadamente, as infrações específicas (arts. 11 a 24) contra a Fauna (secções I); idem, contra a Flora (arts. 25 a 48); idem em relação a outras infrações ambientais (arts. 41 a 48); idem contra o Ordenamento Urbano e o Patrimônio Cultural (arts. 49 a 52); idem, contra a Administração Ambiental (arts. 53 a 59).

Portanto, todas essas infrações e as respectivas multas só podem ser aplicadas pelo órgão federal competente, não sendo dado aos órgãos estaduais, municipais, do D.F. e dos Territórios, o direito de aplicarem tais sanções nos casos indicados, com base diretamente no decreto federal, pena de inconstitucionalidade do auto de infração.

5. Um último aspecto, relativo ao novo decreto, haverá de ser analisado.

Será possível, em princípio, que alguém, ao examinar as diversas hipóteses de infrações detalhadas, de natureza administrativa, relativas ao meio ambiente, encontre, em algumas delas, conteúdos puramente locais e/ou estaduais, e que, portanto, possa entender que não seria dado à União (no caso do IBAMA) vir a aplicar as sanções mencionadas em casos que tais. Estará correta tal interpretação, tendo em vista a distribuição de competências constitucional.

\section{III - A administração Pública e a responsabilidade civil (objetiva) do poluidor}

Na legislação brasileira apareceu pela primeira vez a eleição da modalidade denominada responsabilidade objetiva (em contraposição à subjetiva, que depende sempre da demonstração da culpa do autor do prejuízo), no Decreto $\mathrm{n}^{\mathrm{9}} 79.347$, de 28.3.77, que promulgou a Convenção Internacional sobre Responsabilidade Civil em Danos Causados por Poluição por óleo, de 1969. Posteriormente, também a Lei $\mathrm{n}^{\circ} 6.453$, de 17.10 .77 , no ser art. $4^{2}$, caput, acolheu a responsabilidade objetiva relativamente aos danos provenientes de atividades nucleares.

Finalmente, a lei $\mathrm{n}^{0} 6.938 / 81$, que dispõe sobre a Política Nacional de Meio Ambiente, consagrou, em termos gerais, a responsabilidade civil objetiva, relativamente a todo e qualquer dano ao meio ambiente. Essa idéia foi de nossa autoria, quando efetuamos sugestões ao então projeto de lei, que nos foi solicitado para exame, no sentido de apresentarmos sugestões, pela então existente SEMA.

$\mathrm{O}$ art. $14, \S 1^{2}$, dispõe: "Sem obstar a aplicação das penalidades previstas neste artigo, é o poluidor obrigado, independentemente da existência de culpa, a indenizar ou reparar os danos causados ao meio ambiente e a terceiros, afetados por sua atividade..."

Tal como foi redigida, confessamos, a disposição não esclarece se o Direito positivo brasileiro abraçou a teoria da responsabilidade objetiva do risco (que admite 
as excludentes da culpa da vítima e da força maior) ou a do risco integral (que inadmite excludentes).

Por essa razão, sentimo-nos na obrigação indeclinável de, aqui e agora, enfrentarmos tal questão: teria o $\S 1^{9}$ do art. 14 da Lei $n^{2} 6.938 / 81$ acolhido a teoria do risco proveito ou a do risco integral, com a expressão" independentemente de existência de culpa"?

Necessitamos aqui nos socorrer dos estudos (vários) efetuados pela doutrina no campo da responsabilidade civil do Estado, que, como sabemos, é de longa data, de ordem objetiva.

Aqui, assevera o Desembargador do Tribunal de Justiça de São Paulo, Álvaro Lazzarini (cf. "Responsabilidade Civil do Estado por Atos Omissivos dos seus Agentes", in Boletim de Direito Municipal, set./91, p. 481): "Das diversas teorias filiadas ao Direito Público, e que não cabem aqui ser examinadas, duas porém, pelo menos no Brasil de hoje, têm causado polêmicas, vale dizer, é ainda, debatida a questão se o constituinte brasileiro acolheu a teoria do risco integral ou da teoria da risco administrativo."

Tratando do assunto, o Prof. Ulderico Pires dos Santos (A Responsabilidade Civil na Doutrina e na Jurisprudência, Forense, $2^{a}$ ed., 1987, p. 514) adianta, em excelente análise de toda a doutrina e da jurisprudência brasileira, que: "171 Responsabilidade civil do Estado - o julgado retrotranscrito tem absoluta pertinência com o critério que deve ser observado sobre o reconhecimento da responsabilidade civil dos concessionários de serviços públicos, que, para esse fim, se equiparam às pessoas jurídicas de direito público.

Estas, como aquelas, só podem desonerar-se do dever de indenizar fazendo a prova de que o evento se deu exclusivamente por culpa de terceiros, ou em razão de fenômenos da natureza absolutamente imprescindíveis". Comenta, após, o Acórdão do $1^{\circ}$ Grupo de Câmaras Cíveis do Tribunal de Justiça do Estado do Rio de Janeiro, cuja ementa era a seguinte: "Responsabilidade Civil do Estado: independe de culpa, embora as pessoas jurídicas de direito público possam desonerar-se da obrigação se provarem culpa de terceiros ou fenômenos da natureza. Ônus da prova. Atos de império e atos de gestões - irrelevância da distinção" (Ap. Cível n 87.990).

Sabe-se que, com efeito, é pacífica, tanto na doutrina como na jurisprudência brasileiras, a tese de que, desde a Constituição de 1946, o Direito pátrio sufragou a teoria do risco administrativo e não a do risco integral.

Assim, Seabra Fagundes já assentou: “Desde que haja um dano, haverá um lugar para a indenização, resulte isto da violação da lei ou não" ( $O$ Controle dos Atos Administrativos pelo Poder Judiciário, Forense, 1957, p. 221).

Nesse sentido, as opiniões de Orozimbo Nonato, Filadelfo de Azevedo, Aguiar Dias, Amaro Cavalcanti, Santiago Dantas, Alcino Paulo Salazar, Martinho Garcez Neto, entre outros. Aguiar Dias afirmou: "Somos, assim, pela aplicação, entre nós, da doutrina do risco administrativo, como a difundida pelo insigne Amaro Cavalcanti, escrevendo que 'assim como a igualdade de direitos, assim, também a igualdade de encargos é hoje fundamental no direito constitucional dos povos civilizados" ( $D a$ Responsabilidade Civil, vol. II, p. 192). 
Enfim, como assevera o Prof. Ulderico Pires do Santos, "é pacífico na doutrina e na jurisprudência que, no tocante à responsabilidade civil das pessoas jurídicas de direito público interno, o princípio sobranceiro, de maior autoridade, é o que consagra o risco administrativo. Este, como se sabe, coloca em ordem inversa o "onus probandi", pois atribui exclusivamente ao Estado a obrigação de provar a ocorrência de caso fortuito, a força maior ou a culpa exclusiva da vítima" (ob. cit., p. 600).

Mas, por que a teoria do risco administrativo e não a do risco integral?

Se formos a Hely Lopes Meirelles, veremos esta sutil explicação: "A Constituição acolheu a teoria objetiva do risco administrativo, revogando em parte o art. 15 do C.C.", mas, "não chegou aos extremos do risco integral", porque "o que a Constituição distingue é o dano causado pelos agentes da Administração (funcionários) dos danos causados por atos de terceiros, ou por fenômenos da natureza. Observe-se que o art. 194 (da Carta de 1946) só atribui responsabilidade objetiva à Administração pelos danos que seus funcionários, nessa qualidade, causem a terceiros. Portanto, o legislador constituinte só cobriu o risco administrativos da atuação, ou inação, dos servidores públicos; não responsabilizou objetivamente a Administração por atos predatórios de terceiros, nem por fenômenos naturais que causem danos aos particulares" (Direito Administrativo Brasileiro, $1^{\text {a }}$ ed., p. 494)

E, "essa também, a orientação que vingou no Egrégio Supremo Tribunal, onde o acatado administrativista é invocado, acrescentando um aresto, que "a contrario sensu", seria admitir a teoria do risco integral, forma radical que obrigaria a Administração a indenizar sempre e que, pelo absurdo, levaria Jean Defroidmont (La Science du Droit Positif, p.339) a cognominar de "brutal' (RTJ, 55/53)" (cf. Ulderico Pires dos Santos, ob.cit. p. 516).

Do exame, portanto, dessas lições doutrinárias e jurisprudenciais relativas à responsabilidade objetiva, retiramos a orientação objetiva da limitação dessa responsabilidade à teoria do risco administrativo: é a redação do dispositivo constitucional que inadmite o acolhimento da teoria do risco integral.

O texto correspondente ao art. 194 da Constituição de 1946 e ao art. 107 da EC n. ${ }^{\circledR} 1 / 69$, é o do $\S 6^{\circ}$ do art. 37 da Constituição de 1988 , verbis:

"As pessoas jurídicas de direito público e as de direito privado prestadoras de serviços públicos responderão pelos danos que seus agentes, nessa qualidade, causarem a terceiros..." (grifos nossos)

Portanto, diante desse texto, que liga umbilicalmente o empenhamento da responsabilidade estatal aos danos que seus agentes causarem a terceiros, permanece incólume aquela orientação doutrinária e jurisprudencial no Direito brasileiro.

Voltemos, portanto, ao texto legal que consagra a responsabilidade objetiva relativamente aos danos ambientais.

Como vimos, o $\S 1^{9}$ do art. 14 da Lei $n^{2} 6.938 / 81$, que a contempla, tem a seguinte redação:

"Sem obstar a aplicação das penalidades previstas neste artigo, é o poluidor obrigado, independentemente da existência de culpa, a indenizar ou reparar os 
danos causados ao meio ambiente e a terceiros afetados por sua atividade" (grifos nossos).

Portanto, segundo esse texto, o poluidor é obrigado a indenizar ou reparar os danos que causar ao meio ambiente, e a terceiros, desde que tanto o meio ambiente como os terceiros venham a ser afetados por sua atividade. Tudo isso sem indagação da existência ou não de culpa do poluidor.

Verifica-se, assim, que o que empenha a responsabilidade do poluidor é a atividade lesiva ao meio ambiente e a terceiros. Fica, portanto, de fora desse quadro qualquer atividade que não possa ser debitada ao poluidor, tais como a ação de terceiros, vítima ou não e, evidentemente, nesse rol, ainda se poderia colocar o caso fortuito (evento causado pela ação humana de terceiros) e a força maior (evento causado pela natureza).

Conclui-se, assim, com base nesses raciocínios jurídicos, à semelhança do que ocorre no âmbito da responsabilidade objetiva do Estado, que, no Direito positivo pátrio, a responsabilidade objetiva pelos danos ambientais é da modalidade do risco criado (admitindo as excludentes da culpa da vítima, da força maior e do caso fortuito) e não a do risco integral (que inadmite excludentes), nos exatos e expressos termos do $\S 1^{9}$ do art. 14 da Lei Federal $n^{9} 6.938 / 81$ - Lei da Política Nacional do Meio Ambiente.

Relativamente à responsabilidade civil por danos nucleares, tanto a Constituição federal (art. 21, XXIII, c - " a responsabilidade civil por danos nucleares independe de existência de culpa"), como a legislação específica (Lei $\mathrm{n}^{2} 6.453$, de 17.10.77, art. $4^{\circ}$, caput), contemplam a responsabilidade objetiva.

Aqui, a modalidade é a do risco administrativo ou do risco criado, por obra da própria lei.

Com efeito, é expressa a Lei $n^{9} 6.453$, de 1977 , ao estabelecer:

"art. $4^{\circ}$ - Será exclusiva do operador da instalação nuclear, nos termos desta lei, independentemente da existência de culpa, a responsabilidade civil pela reparação de dano nuclear causado por acidente nuclear..."

"art. $6^{\circ}$ - Uma vez provado haver o dano resultado exclusivamente de culpa da vítima, o operador será exonerado, apenas em relação a ela da obrigação de indenizar."

"art. $8^{\varrho}-\mathrm{O}$ operador não responde pela reparação do dano resultante de acidente nuclear causado diretamente por conflito armado, hostilidades, guerra civil, insurreição ou excepcional fato da natureza."

"art. $9^{9}$ - A responsabilidade do operador pela reparação do dano nuclear é limitada, em cada acidenta, ao valor correspondente a um milhão e quinhentos mil ORTNs.

Parágrafo único - O limite fixado neste artigo não compreende os juros de mora, os honorários advocatícios e as custas judiciais." 
"art. 10 - Se a indenização relativa a danos causados por determinado acidente nuclear exceder ao limite fixado no artigo anterior, proceder-se-á ao rateio entre os credores, na proporção de seus direitos."

"art. 12-O direito de pleitear indenização com fundamento nesta lei prescreve em 10 (dez) anos, contados da data do acidente nuclear.

Parágrafo único - Se o acidente for causado por material subtraído, perdido ou abandonado, o prazo prescricional contar-se á do acidente, mas não excederá a 20 (vinte) anos contados da data da subtração, perda ou abandono."

"art. 13 - O operador da instalação nuclear é obrigado a manter seguro ou outra garantia financeira que cubra a sua responsabilidade pelas indenizações por danos nucleares."

Cabe então afirmar que, segundo a legislação específica, a responsabilidade civil por dano nuclear, por expressa disposição legal, é a da modalidade do risco criado e não a do risco integral.

Registre-se que o Prof. Carlos Alberto Bittar, em obra excelente e dedicada exclusivamente ao assunto, analisando a lei brasileira (Responsabilidade Civil nas Atividades Nucleares, Ed. Revista dos Tribunais, 1985, p.211), observa: "Na diretriz geral encontra-se a lei brasileira, que nada de peculiar oferece a respeito, nas três disposições em que versa a matéria.

De fato, estabelece, inicialmente, que provado haver o dano resultado exclusivamente de culpa da vítima, o operador será exonerado, apenas em relação a ela, da obrigação de indenizar' (art. $6^{\circ}$ ).

Trata-se da exoneração da culpa da vítima, em que admite também a forma "stricto sensu".

Estipula-se, ao depois, que o operador 'somente tem direito de regresso contra quem admitiu, por contrato escrito, o exercício desse direito, ou contra pessoa física que, dolosamente, deu causa ao acidente (art. $7^{2}$ ).

São os mesmos casos previstos na grande maioria das leis referidas, prevalecendo, nesse passo, entre nós, apenas o dolo."

Quanto à limitação da responsabilidade, prevista nos arts. $9^{\circ}$ e 10 da Lei $n^{\circ}$ $6.453 / 77$, salienta o autor em nota de rodapé:

"A limitação da responsabilidade - cuja constitucionalidade foi posta em debate judicial nos EUA, conforme discutido em seus diferentes contornos, por Renato Guimarães Jr. ('O Seguro Nuclear sob risco constitucional', in RT, v523, p.275), teve, entre nós, indicação nesse sentido, no Instituto dos Advogados Brasileiros, em que se cogitou de possível colisão entre certos textos da Lei n. ${ }^{9}$ $6.453 / 77$ (arts. $4^{\circ}, 7^{\circ}, 8^{\circ}, 9^{\circ}$ e $10^{\circ}$ ) e $o$ art. 107 da Constituição federal (anterior). Mas Nino Machado Faria ('Responsabilidade Civil por danos nucleares', Rio de Janeiro, IAB, 1981 - parecer) demonstrou a inexistência de conflito, enfatizando o caráter especial da responsabilidade em causa e seu restrito campo de 
aplicação (às atividades nucleares previstas). Ademais, inbostante certas formulações - como vimos - destoem do regime normal de responsabilidade civil, a verdade é que, entre nós, inexiste, em qualquer das situações referidas, mandamento constitucional em contrário" (ob. cit., p. 199).

\section{IV - A responsabilidade ou criminalização dos atos danosos ao meio ambiente}

Não seria, à evidência, possível uma proteção eficaz do ambiente, sem a colaboração do Direito Penal. Por isso, as legislações dos vários países contemplam diversas condutas atentatórias ao meio ambiente como sendo crimes ou contravenções.

Paulo José da Costa Jr. e G. Gregori afirmam, a propósito:

"A previsão de crimes especificamente ecológicos, esteja ela compreendida no Código Penal ou expressa em leis especiais é, de qualquer modo, a única forma para assegurar aos valores ambientais aquela proteção 'imediata' de que necessitam no momento atual", surgindo, "assim, no direito penal recente, uma tipologia de seus interesses ecológicos que se apresentam sempre, em todas as experiências legislativas que se vêm a fazer na matéria". (Paulo J. da Costa Jr. e Giorgio Gregori, Direito Penal Ecológico, CETESB, 1981, p.46).

Asseveram ainda:

"A complexidade e a precariedade da matéria penal ecológica tornam não sempre fácil a exata individualização do bem jurídico tutelado por determinada proposição incriminadora. $\mathrm{Na}$ atualidade, em todas as ordenações penais que se mostrem amadurecidas, existe um complexo de normas que, mesmo diferindo em seu objeto que integra a categoria 'segurança' da 'conservação' do ambiente natural. Tudo isso se reveste de grande importância de um ponto de vista sistemático".

Esses eminentes penalistas, antes de mais, descrevem e analisam a questão fundamental nesta matéria: a construção do tipo no âmbito do Direito Penal Ecológico.

Indicam que, em primeiro lugar, existe a tendência em acentuar, na construção da norma penal em questão, a indicação do "fim" perseguido, em prejuízo da descrição precisa do "fato" vetado. Entendem que, na aplicação, esse tipo de norma confia grande discricionariedade ao juiz e presta-se felizmente aos destinos incertos de uma interpretação evolutiva (o tipo tende, portanto, a assumir um caráter exemplificativo) (ob. cit., p. 49).

Acrescentam que a indeterminação dos tipos demonstra que a atitude legislativa não se deve à incapacidade do legislador moderno de forjar um sistema normativo analítico (exaustivo), mas sim à ansiedade de proteger a qualquer preço bens que estão sendo destruídos, de maneira progressiva e irrecuperável. O caráter indeterminado do tipo visa, portanto, em muitos casos, punir o maior número de condutas poluentes. Assim, concluem que, no estado atual das coisas, não é possível tutelar diversamente, de forma adequada, os bens ecológicos. Essa constatação termina por enfatizar que, na construção da norma penal ecológica, deve-se em grande parte 
prescindir da conduta vetada, para concentrar a maior atenção nas características e nos tipos de lesão que ofendem o bem protegido (ob., cit., pp.53-54).

Por isso, por essa questão fundamental, de técnica legislativa em matéria penal vetorializada aos delitos ecológicos, os juristas referidos nos adiantam que a construção da lesão- tipo dos bens jurídicos em questão aproxima-se muito mais da fronteira do "perigo", que daquela do "dano", e que essa regra vem praticamente generalizada, em matéria de crimes de poluição atmosférica ou marítima. (ob. cit., p.55).

Quanto ao crime de dano ecológico, ocorre sempre que a tutela emprestada ao bem natural considere o momento em que se verificam os fatos da inquinação, e o dano constitui-se numa alteração da situação preexistente em razão da ação de determinado sujeito, o crime comportará a valoração da lesão efetiva de um bem ambiental. Por isso, hipóteses de crimes de danos, nesse campo, não são frequientes, porque, na prática, são de difícil aplicação. (ob. cit., p.55).

Quanto ao crime ecológico ser enquadrável como crime de perigo, adiantam os autores que tal concepção exerce sobre o legislador enorme atração, porque ela torna o problema mais simples. (ob.cit.,p.56).

Doutrinando que se verifica o crime de perigo sempre que a lei transfira o momento consumativo do crime da "lesão" para aquele da "ameaça", aperfeiçoando-se o crime no instante em que o bem tutelado encontrar-se numa condição objetiva de possível ou provável lesão, indicam que dessa forma, obtém-se a confortadora perspectiva de vencer a fronteira protetora dos bens e valores, merecedores de especial tutela. Concluem que, em verdade, no contexto da sociedade contemporânea, torna-se evidente que uma técnica normativa assentada na incriminação do perigo é a mais adequada a enfrentar as ameaças múltiplas trazidas de muitas partes e por meios estranhos ao sistema ecológico. (ob.cit.,p.57).

Por fim, observam que a doutrina tradicional costuma apresentar uma "summa divisio" entre crimes de perigo "concreto" e "abstrato" ou "presumido", fundamentando a diferença no fato de que, nos primeiros, a existência do perigo deve ser averiguada caso por caso, ao passo que, nos demais, prescinde-se de tal averiguação, já que a ameaça ao bem tutelado é deduzida da lei, pelo simples fato de estarem os extremos de conduta integrados no tipo (afirmam que a literatura a respeito é vasta) (ob.cit.p.57). Em ambos os casos, porém, os seus fundamentos estão na convicção incontroversa do legislador de que a conduta em exame constitui-se numa ameaça ao bem ambiental protegido.

Invocam esses autores o testemunho de Herman (Die Rolle...) quando observou que, via de regra, são os tipos de perigo abstrato que marcam os tipos fundamentais da moderna tutela penal do meio ambiente; ao passo que os tipos de perigo concreto não representam as mais significativas confirmações (ob.cit., p.60).

É importante, para se entender as características de proteção penal do meio ambiente no mundo contemporâneo, a observação desses autores:

"Note-se: nos termos modernos, a tendência é antecipar a proteção do ambiente natural, do momento do dano ao momento do exercício da atividade perigosa aos bens ecológicos, quando não do instante da simples detenção ou produção 
de substâncias poluentes. A atenção do legislador tem sido cada vez maior nesse sentido, obcecada que se acha pela necessidade de prevenir o fenômeno, reprimindo as condutas predatórias. Afastam-se os crimes ecológicos, consequientemente, sempre mais da lesão efetiva do bem jurídico, para construírem uma linha avançada de defesa contra a poluição".

(ob.cit., pp.60-61)

Mas observam que na doutrina mais atenta e nas experiências legislativas de vanguarda vai se afirmando um outro modo de considerar o problema. Partidas das dificuldades sabidas de encontrar o legislador penal, para delimitar o âmbito e a intensidade da tutela a ser emprestada aos bens ambientais, sugere-se que a proteção do ambiente seja confiada principalmente à autoridade administrativa, a quem cabe a obrigação de regulamentar os fatores poluentes, de conceder autorizações para o exercício de atividades perigosas, de impor limitações, cautelas e proibições com relação a eles. O Direito Penal viria a desenvolver função secundária de punir a violação de prescrição administrativas. O crime ecológico então consistiria em mera desobediência aos preceitos da autoridade estatal competente em disciplinar o uso dos recursos ambientais (ob.cit., p.67).

Adentra-se, assim, neste campo, à utilização das denominadas "normas penais em branco", de aceitação pacífica na doutrina, mesmo tradicional, do Direito Penal. Essa técnica foi a utilizada pelo legislador da Lei $\mathrm{n}^{9} 6.766$, de 1979, que disciplina, no Brasil, o parcelamento do solo urbano (arts.50 e ss.)

Entretanto, para fins de análise e reflexão é importante considerar que essa tendência legislativa - a preferência pelas normas penais em branco - se dá na Europa, enquanto que na América latina a tendência evolutiva é oposta.

Mostra-nos esse fato, com muita nitidez, o ilustre jurista ambiental brasileiro, Prof. Paulo Affonso Leme Machado:

"Os textos das reformas penais introduzidas no Brasil mostram uma sensível diferença entre o conteúdo incriminatório dos arts. 15 e 16 da Lei de Agrotóxicos e o novo art.15 da Lei ${ }^{\circledR}$ 6.938/81. Na lei de Agrotóxico aplicou-se o sistema de um Direito Penal Administrativo, procurando-se diretamente apoiar o corpo de normas administrativas relativas ao registro, comercialização, transporte e aplicação de pesticidas. Já na reforma levada a efeito pela Lei $n^{0} 7.804 / 89$ está caracterizada a autonomia da norma penal frente às normas administrativas" (Direito Ambiental Brasileiro, $3^{a}$ ed., RT, 1991, p.364).

Indica-se que, na Alemanha Federal, em 1990, foi introduzido um capítulo intitulado "Delitos contra o Meio Ambiente" no Código Penal, e na Espanha, em 1983, inseriram no Código Penal artigos tratando do meio ambiente. Em ambos os casos, vamos verificar que o tipo penal só se realiza se houver descumprimento de normas administrativas protetoras do meio ambiente. Na América Latina, entretanto, ocorre o contrário, ou seja, a menos que a lei não contenha preceitos reguladores e protetores do meio ambiente, os Poderes Executivos não se têm mostrado ágeis e com vontade política determinante para punir a agressão ambiental. 
Assim, no México, a Lei de Meio Ambiente, de 11.1.82, em seu art.76, não deixa em branco a incriminação penal ambiental. Da mesma forma, no Brasil, com seu art.15 advindo da Lei no $7.804 / 89$ (ob., cit., p.364).

Visto isso, considerações fundamentais na matéria, feitas por eminentes e conceituados penalistas pátrios, vejamos como o Direito Positivo criminaliza os ilícitos contra o meio ambiente no Brasil.

Desde logo, destaque-se, há não só crimes, como, também, contravenções.

O diploma fundamental aqui, é sem dúvida a Lei no 7.804 , de 18.7.89, que modificando $o$ art. 15 da Lei $n^{\circ} 6.938$ de 31.8.81, dispôs: $O$ poluidor que expuser $o$ perigo a incolumidade humana, animal ou vegetal, ou estiver tornando mais grave a situação de perigo existente, fica sujeito à pena de reclusão de um a três anos e multa de 100 a 1.000 MVR".

Há aumentos da pena em dobro se: I — resultar: a) danos irreversível à fauna, à flora e ao meio ambiente; b) lesão corporal grave; II - a poluição é decorrente de atividade industrial ou de transporte; III - o crime é praticado durante a noite, domingo ou feriado.

As autoridades competentes que deixarem de promover as medidas tendentes a impedir a prática das condutas mencionadas incorrerão no mesmo crime, segundo o $\S 2^{\circ}$ do referido artigo.

Pode-se considerar que a Lei $\mathrm{n}^{9} 7.804$, de 1989, veio regulamentar o art. 225, $\S 3^{e}$, da Constituição Federal, em parte, posto que a disposição constitucional previu sanção penal também para as pessoas jurídicas, e a disposição transcrita não abrangeu expressamente, o que, em Direito Penal, é de rigor, não cabendo ao intérprete pretender incluí-la na expressão "poluidor".

De outros lado, observe-se que é um tipo penal genérico, de perigo concreto e não abstrato, de resultado, e autônomo em relação às regras administrativas (não se trata de norma penal em branco).

Em seguida, a Lei de Agrotóxicos tipificou os crimes de poluição e mau uso de agrotóxicos (Lei $n^{\circledR} 7.802$, de 11.7.89). O legislador aqui utilizou-se da técnica das normas penais em branco.

Quanto à caça, o Código de Caça (Lei n⿳⺈ 5.197, de 3.1.67) ou Lei de Proteção à Fauna, continha normas apenas relativas às contravenções. A Lei ${ }^{9} 7.653$, de 12.2.1988, tornou essas contravenções, crimes, tornando-os inafiançáveis, tendo havido revogação parcial dela, através da lei $\mathrm{n}^{\circ} 7.679$, de 23.11.1988.

O Decreto $\mathrm{n}^{2} 23.793$, de 23.1.1934, era o Código Florestal, tendo dividido as infrações penais sobre o assunto em crimes e contravenções penais. $\mathrm{O}$ código penal de 1940, através do art. $3^{\circ}$ da Lei de Introdução, considerou que os crimes do Código Florestal, quando não inseridos nele (Código Penal), passariam a ser contravenções. Com o novo Código Florestal (Lei no 4.771, de 15.9.1965) as contravenções ficariam na lei especial e os crimes permaneceram regulados no Código Penal.

O Código Penal (Dec-Lei n⿳ำ 2.848, de 7.12.1940, com alterações) prevê vários outros crimes em matéria ambiental, tais como: incêndio doloso em florestas (art. $250, \S 1^{\circ}$, com pena de reclusão; incêndio culposo de florestas (art. $250, \S 2^{\circ}$ ); difusão dolosa de epífitos ou pragas (art. 259); difusão culposa (art. $259, \S 1^{\circ}$ ); dano em floresta particular (art. 163); dano em floresta de entes políticos e suas entidades 
(art. 163); dano por abandono de animais em floresta (art. 164); resistência, desobediência e desacato (arts. 329 a 331); furto (art. 155); envenenamento de água potável ou de substância alimentícia (art. $270, \S 2^{\circ}$ - modalidade culposa; Lei ${ }^{\circ}$ 8.072 , de 25.7 .90 - crime hediondo, pena de reclusão de 10 a 15 anos); corrupção ou poluição de água potável (comum ou particular - art. 271 do CP); falsidade e uso de documento público (arts. 297 e 304 do CP).

A análise detalhada de todos os crimes e contravenções no Direito Brasileiro pode ser realizada na obra Crimes contra a Natureza, $2^{\mathbf{a}}$ ed., Rev. Tribs., de Vladimir Passos de Freitas e Gilberto Passos de Freitas, 1991, por todos os títulos o melhor trabalho já produzido entre nós, no assunto.

\section{As recentes sanções penais}

A Lei $\mathrm{n}^{0}$ 9.605, de 12.02.98 (DOU-13.02.98), veio dispor sobre as sanções penais e administrativas, derivadas de condutas e atividades lesivas ao meio ambiente.

Essa lei veio complementar a Lei $n^{2} 7.804$, de 1989, regulamentando o art. 225, $\S 3^{\circ}$, da Constituição Federal, disciplinando os crimes ecológicos com maiores detalhamentos, fixando a responsabilidade penal e administrativa das pessoas jurídicas e contemplando normas gerais relativas às sanções administrativas.

Neste ponto, faremos rápidas considerações sobre os aspectos gerais da referida Lei:

$\mathrm{O}$ art. $1^{\circ}$ dizia que as condutas e as atividades lesivas ao meio ambiente seriam punidas com sanções administrativas, civis e penais, na forma estabelecida nesta lei. O Presidente da República vetou esse artigo tendo em vista que o dispositivo abrangia apenas as sanções previstas em lei, e com isto, outros ilícitos tipificiados em legislações outras deixariam de existir.

$\mathrm{O}$ art. $2^{\circ}$ contempla a co-autoria, que, neste caso, é sempre culposa (na medida da culpabilidade).

Como se sabe, o art. 29 do Código Penal, tema de concurso de agentes, adotou a teoria monística ou unitária, equiparando, em princípio, todos aqueles que, de qualquer modo, concorrem para o crime. Autores ou cúmplices respondem, igualmente, pela totalidade do evento criminoso.

De outro lado, aponte-se: a fórmula concisa do art. 29 do CP ("quem, de qualquer modo, concorrer para o crime incide nas penas a este cominadas na medida de sua culpabilidade"), é corolário da teoria da equivalência das causas, adotadas pelo mesmo Código ("O resultado de que depende a existência do crime, somente é imputável a quem lhe deu causa. Considera-se causa a ação ou omissão sem a qual o resultado não teria ocorrido" - art. 13 do $\mathrm{CP}$ ).

Uma característica, entretanto, deste art. $2^{\circ}$, é que a co-autoria é de natureza culposa.

A propósito, lembre-se da lição oportuna da Prof Ivete Senise Ferreira, da USP: 
"Sem entrar em maiores considerações a respeito da culpabilidade na moderna doutrina brasileira, que parece ser tanto psicológica quanto normativa, importa sobretudo lembrar que os crimes ecológicos tanto podem ser dolosos como culposos, mas de acordo com a regra do art. 18 do Código Penal, válida também para a legislação especial, os crimes culposos só serão puníveis quando expressamente forem mencionados na lei; no silêncio destes subentende-se terem sido previstos apenas na forma dolosa" ("O direito penal ambiental", Ver. Consulex. $\mathrm{n}^{2} 7$, p.30, jul.1997).

Ainda, o art. $2^{\circ}$ abrange como co-autores o diretor, administrador, o membro do conselho e do órgão técnico, o auditor, o gerente, o preposto ou mandatário de pessoa jurídica, que sabendo da conduta criminosa de outrem, deixa de impedir a sua prática, quando pode agir para evitá-la.

Portanto, especificamente em relação a esses agentes, o crime ocorrerá se eles, sabendo da conduta criminosa de outrem e, podendo agir para evitá-la, se omitirem. Trata-se, no caso, da participação omissiva, que segundo a doutrina penalista, só pode ser imputada a quem tenha o dever de evitar o evento criminoso. Quem não têm o dever jurídico de evitar o crime, não pode ser considerado co-autor ou partícipe por omissão.

O art. $3^{\circ}$, concretizando, como já se disse, o art. $225, \S 3^{\circ}$ da Constituição Federal, impõe a responsabilização penal, administrativa e civil da pessoa jurídica, avançando nesse aspecto, na trilha de uma das modernas legislações a respeito.

Entretanto, a norma é objetiva: tais responsabilidades somente emergirão quando:

a) ocorrerem os ilícitos previstos na Lei $\mathrm{n}^{0}$ 9.605/98.

b) nos casos em que a infração seja cometida por decisão de seu representante legal ou contratual, ou de seu órgão colegiado, no interesse ou benefício da sua entidade.

$\mathrm{O}$ art. $4^{9}$ contempla, pela primeira vez, no direito positivo ambiental, a teoria da desconsideração da personalidade jurídica da pessoa coletiva, desde que o seu uso constitua obstáculo ao ressarcimento de prejuízos causados à qualidade do meio ambiente.

O art. 59, vetado pelo Presidente da República, tinha a seguinte dicção: "Sem prejuízo do disposto nesta Lei, o agente, independentemente da existência de culpa, é obrigado a indenizar ou reparar o dano por ele causado ao meio ambiente e a terceiro afetados por seus atos".

O veto oposto sublinhou que a redação do art. $14, \S 1$ 이 da lei n.. 6.938/91 (que contempla já a responsabilidade objetiva, por redação nossa dada ao então anteprojeto da Lei de Política Nacional do Meio Ambiente, que nos foi submetida, a nós e ao eminente jurista Paulo Affonso Leme Machado) afigura-se mais consentânea com a terminologia utilizada nas questões ambientais.

$\mathrm{O}$ art. $7^{\circ}$ contempla uma diretriz fundamental seguida pela lei e, sob esse aspecto, tal explicação nos foi dada pela eminente Desembargador, Dr. Gilberto Passos de Freitas, Presidente da Comissão que elaborou o então anteprojeto da Lei: a substituição das penas privativas de liberdade pelas penas restritivas de direito (que são 
autônomas), nas hipóteses elencadas ( $I$ - quando tratar-se de crime culposo ou for aplicada a pena privativa de liberdade inferior a quatro anos; II - quando a culpabilidade, os antecedentes, a conduta social e a personalidade do condenado, bem como os motivos e as circunstâncias do crime indicarem que a substituição seja suficiente para efeitos de reprovação e prevenção do crime).

O Parágrafo único impõe às penas restritivas de direitos, à reprovação e prevenção de direitos, a mesma duração da pena privativa de liberdade a que substituiu.

$\mathrm{O}$ art. 8 indica quais são, para as pessoas físicas, as penas restritivas de direito: I - prestação de serviços à comunidade; II — interdição temporária de direitos; III — suspensão parcial ou total de atividades; IV - prestação pecuniária; V recolhimento domiciliar.

Já o art. 21 dispõe que as penas aplicáveis à pessoa jurídica (isolada, cumulativa ou alternativamente) de acordo com o art. 3o, são: I — multa; II — restritivas de direitos e III - prestação de serviços à comunidade.

$\mathrm{O}$ art. 22 diz quais são as penas restritivas de direitos da pessoa jurídica: $\mathrm{I}$ suspensão parcial ou total de atividades; II - interdição temporária de estabelecimento, obra ou atividade; III - proibição de contratar com o Poder Público, bem como dela obter subsídios, subvenções ou doações.

A diferença entre suspensão e interdição está no seguinte aspecto: na primeira hipótese, a atividade não está obedecendo às disposições legais ou regulamentares, relativas à proteção do meio ambiente; na segunda hipótese o estabelecimento, obra ou atividade estará funcionando sem a devida autorização, ou em desacordo com a concedida, ou com violação de disposição legal ou regulamentar.

A pena do inc. III, ou seja, a proibição de contratar com o Poder Público não poderá exceder o prazo de $10(\mathrm{dez})$ anos $\left(\S 3^{9}\right)$.

$\mathrm{O}$ art. 23 indica no que consistirá a pena de prestação de serviços à comunidade: I - custeio de programas e projetos ambientais; II - execução de obras de recuperação de áreas degradadas; III - manutenção de espaços públicos; IV — contribuição às entidades ambientais ou culturais públicas.

$\mathrm{O}$ art. 25 trata da apreensão do produto e do instrumento do crime ou de infração administrativa.

Os arts. 26 a 28 dão nova disciplina aos crimes ambientais de menor potencial ofensivo (Lei $\mathrm{n}^{2}$ 9.099, de 26.09.95).

O Capítulo V dispõe, especificamente, sobre os "Crimes contra o Meio Ambiente".

Na Seção I, através dos arts. 29 a 37, elenca os tipos penais relacionais aos crimes contra a fauna. Na Seção II, elenca aqueles relacionados com a flora.

A seção III tipifica (arts. 54 a 61) os crimes de poluição e outros. Aqui, é de ser salientado o art. 60, que se constitui numa norma penal em branco, posto que remete a sua complementação à área administrativa.

A seção IV trata dos crimes contra o ordenamento urbano e o patrimônio cultural.

O art. 62 tipifica o crime de destruição, inutilização ou deteriorização de bens culturais ou monumentais. 
$\mathrm{O}$ art. 63 completa o anterior, com a mesma preocupação, abrangendo bens de valor turístico, paisagístico, histórico, religioso, arqueológico, etnográfico e ecológico. $\mathrm{O}$ art. 64 protege o entorno de bens daquelas espécies.

A Seção V dispõe sobre os crimes contra a administração ambiental.

$\mathrm{O}$ art. 67 contempla norma penal em branco e o art. 68, crime de omissão funcional ou contratual.

$V$ - Comunicabilidade e incomunicabilidade das instâncias penais, administrativas e civil

Vimos que o poluidor ou depredador do meio ambiente pode ser responsabilizado administrativamente, civil e penalmente.

Necessitamos agora saber, se, no caso de haver a responsabilização administrativa, a penal e a civil, se cada uma dessas instâncias, relativamente às decisões nelas proferidas em relação a determinado poluidor ou depredador do meio ambiente, têm ou não influência, as decisões respectivas, umas sobre as outras.

O código de Processo penal trata da questão no seu art. 386, incisos I a VI, "in verbis":

"Art. 386 - O juiz absolverá o réu mencionado a causa na parte dispositiva, desde que reconheça:

I - estar provada a inexistência do fato;

II - não haver prova da existência do fato;

III - não constituir, o fato, infração penal;

IV - não existir prova de ter o réu concorrido para a infração penal;

$\mathrm{V}$ - existir circunstância que exclua o crime ou isente o réu de penas (arts. 17, $18,19,22$ e $24, \S 1^{2}$, do C.P.)"

VI - não existir prova suficiente para a condenação."

Vejamos, em primeiro lugar, a repercussão da sentença penal, condenatória ou absolutória, no juízo administrativo.

Assim, segundo tais regras, uma primeira hipótese é aquela em que o juízo criminal reconhece a inexistência do fato, e a segunda é aquela em que o juízo criminal, reconhece a existência do fato, mas entende que o poluidor não é o autor do fato danoso ao meio ambiente. Em ambas as hipóteses há repercussão da decisão criminal na jurisdição administrativa. Ou seja, existe a comunicabilidade de instâncias. Em consequiência, as decisões judiciais, nesses casos, obrigam que as instâncias administrativas absolvam o poluidor.

Como lembra, em outro aporte, José Cretella Jr. (Manual de Direito Administrativo, Forense, Rio de Janeiro, $2^{2}$ ed., 1979, p.370):

"Se o fato constitui ilícito administrativo e, ao mesmo tempo, ilícito penal, a decisão do juiz criminal que declara inexistente o fato ou que o funcionário não foi seu autor, é válida, e repercute na instância administrativa, no que tange ao crime; se resta, porém, um resíduo, uma falta administrativa, esta é suficiente para a condenação administrativa." 
Adianta outras hipóteses o ilustre professor: “Entretanto, a absolvição no juízo penal, nos casos de inexistência, insuficiência de prova, em nada influi sobre o juízo administrativo e disciplinar.

A absolvição de funcionários público, que resulta da ineficiência de prova é inoperante no campo administrativo.

Para a condenação, na esfera penal, é imposto um rigor bem maior do que para a aplicação de uma pena administrativa. A prova que será suficiente na esfera administrativa para demissão, não é bastante na esfera penal para condenação: é a insuficiência de prova."

Nesta última hipótese há a incomunicabilidade das instâncias.

Entretanto, o professor não abordou a hipótese da condenação no juízo criminal. Há repercussão desta condenação na esfera administrativa, pela mesma razão apontada pelo professor, para a hipótese da insuficiência de prova, quando admite-se que o juízo penal é muito mais rigoroso que a instância administrativa; deve-se concluir que a repercussão da decisão condenatória do juízo criminal é plena e imediata na via administrativa. Ou seja, o poluidor condenado na via criminal o será, só por isso, também na via administrativa.

E, em matéria ambiental, não pode ser diferente, principalmente quando se tratarem de processos administrativos e judiciais, cujos ilícitos são os mesmos, ou seja, são, ao mesmo tempo, tipificado como ilícitos penais e administrativos (é o caso dos ilícitos administrativos a seguir pinçados do Decreto $\mathrm{n}^{2} 3.179$, de 21.09.99 e suas correspondente, e idênticas tipificações penais, previstas na Lei $\mathrm{n}^{0} \mathbf{9 . 6 0 5}$, de 12.2.1998: art. 11, correspondente ao art. 29 da Lei $\mathrm{n}^{2} 9.605$; art. 13, ao art. 30; art. 17 ao art. 32 ; art. 18 ao art. 33 ; art. 19 ao art. 34 ; art. 20 ao art. 35 ; art. 25 ao art. 38 ; art. 26 ao art. 39 ; art. 27 ao art. 40 ; art. 28 ao art. 41 ; art. 29 ao art. 42 ; art. 30 ao art. 44; art. 31 ao art. 45; art. 32 ao art. 46; art. 33 ao art. 52; art. 41 ao art. 54; art. 42 ao art. 55 ; art. 43 ao art. 56 ; art. 44 ao art. 60 ; art. 45 ao art. 61 ; art. 49 ao art. 62; art. 50 ao art. 63; art. 51 ao art. 64).

Nessas hipóteses, sem dúvida nenhuma, a repercussão da condenação penal na esfera administrativa é de rigor posto que as provas e o rigor no processo criminal são muito mais exigentes do que na esfera administrativa. Já o contrário, ou seja, a repercussão, nos casos supra indicados, de uma condenação na esfera administrativa, posto que menos exigentes os seus pressupostos, daqueles do juízo criminal, não têm repercussão; quando muito, serão, as provas colhidas, início de prova no juízo criminal.

Quanto às responsabilidades, penal e civil (objetiva), inexiste qualquer comunicabilidade entre as duas, posto que, na primeira, há que se buscar sempre o ato doloso (ou, excepcionalmente, o culposo), sendo certo que, na segunda, não há que se buscar sequer a culpa; bastam o nexo causal e o dano efetivamente causado pelo poluidor/depredador do meio ambiente. 


\section{Família e Igualdade}

Carlos David S. Aarão Reis

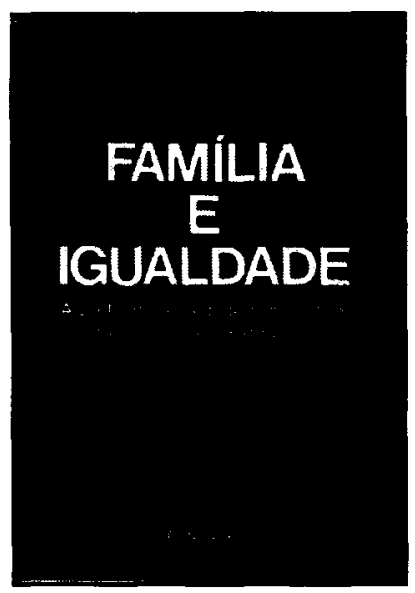

A leitura deste livro fixa, com muita propriedade, a noção de um tema em que muitos falam e poucos assimilam: a igualdade. Enfrentando a questão proposta de forma definitiva, com rigorosa competência e absoluto domínio da doutrina e valendo-se, ainda, de impecável metodologia. Esta obra representa admirável contribuição às letras jurídicas nacionais.

$\begin{array}{lll}\text { Ref. 0043 } & \text { Brochura } & 134 \text { págs. } \\ \text { Form. 14x21 } & 1992 & \end{array}$

\section{Filosofia do Direito}

Nelson Saldanha

Este livro apresenta, dentro de uma linha temática bastante ampla e abrangente, os temas fundamentais da filosofia do direito. Sem recorrer a uma exposiçāo puramente histórica das matérias, que em tantos casos substitui a reflexāo sistemática, a obra se baseia contudo sobre um tratamento substancialmente histórico dos problemas, vistos sob angulação didática e ao mesmo tempo pessoal. Incluindo as questōes epistemológicas, as ontológicas e as axiológicas, o livro conduz a uma série de itens sobre hermenêutica jurídica, envolvendo o hoje tão discutido tema das normas e dos princípios.

Ref. 0159

Form. 14x21

Brochura

236 págs. 1998

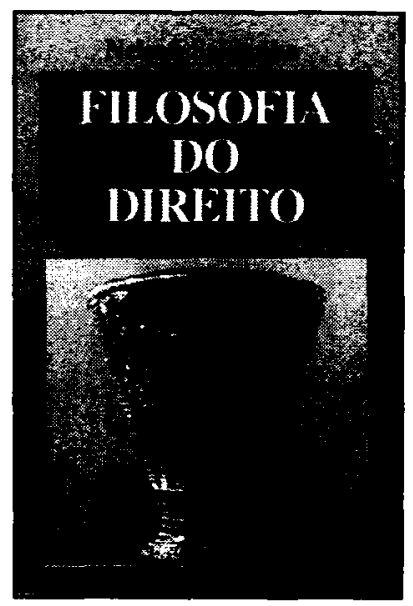

